\title{
Pendidikan Pemilih dan Penguatan Demokrasi
}

\section{Ahmad Imron Rozuli, Muhtar Haboddin}

Fakultas Ilmu Sosial dan Ilmu Politik, Universitas Brawijaya

Email:muhtar_haboddin@ub.ac.id

\begin{abstract}
Abstrak: Tulisan ini berusaha menelaah tautan antara pendidik pemilih dengan politik kewarganegaran di satu sisi, sementara di sisi yang lain mengaitkan pendidikan pemilih dengan penguatan demokrasi. Cara pandang ini sangat berbedah dengan kajian pendidikan pemilih, yang menempatkan pemilu sebagai fokus sentralnya. Bagi penulis, pendidikan pemilih perlu diperluas maknanya dengan mengaitkan politik kewarganegaraan dan demokrasi. Pendidikan pemilih berkontribusi menciptakan warganegara yang cerdas, kritis, dan rasional dalam menggunakan hak politiknya. Pada saat yang sama, mandiri dan bebas dalam menyuarakan tuntutan, keinginan, dan kepentingan politiknya. Lebih jauh lagi, hasil dari pendidikan pemilih memungkinkan warganegara melakukan kontrol terhadap kinerja pemerintahan dalam menjalankan tugas dan fungsinya. Dengan kata lain, pendidikan pemilih akan menambah kapasitas warganegara bila berhadapan dengan pemerintahan.
\end{abstract}

Kata kunci: Demokrasi; Kewarganegaran; dan Pendidik Pemilih.

\begin{abstract}
This paper examines both the relationship between the voter educators and the politics of citizenship, and between the former variable and the empowerment of democracy. This perspective differs greatly from the study of voters' education, which places the election as the core focus. For the author, the notion of voters' education needs to be associated with the politics of citizenship and democracy. Education contributes to the presence of smart, critical, and rational citizens who exercise their political rights, simulteniuosly being independent and free to voice their political demands, wills, and interests. Further, the outcome of educating the voters allows them to monitor the performance of their government in carrying out their duties and funtions. The education of the voters will promote their capacity to deal with the government.
\end{abstract}

Keywords: Democracy; Citizenship; and Voter Educators. 


\section{Pendahuluan}

Caroline Paskarina, dkk. Menyebutkan, bahwa Demokrasi adalah jalan yang memungkinkan pemilih menjadi berdaya dan berdaulat. ${ }^{1}$

Pendidikan pemilih merupakan bagian penting dalam pemilu maupun demokrasi. Begitulah kesan yang muncul ketika membaca pendidikan pemilih yang ditulis beberapa sarjana. Misalnya, Wollack², Prihatmoko $^{3}$, Suryanef ${ }^{4}$, Manik ${ }^{5}$, Arinanto ${ }^{6}$, dan Santoso ${ }^{7}$. Semua penulis tersebut mengkaji pendidikan pemilih dengan mengaitkan pemilu dan pemilih pemula. Pendidikan pemilih merupakan bagian dari penyelenggaraan pemilu. Sedangkan pemilih pemula merupakan salah satu isu penting yang mendapat perhatian baik bagi penyelenggara pemilu maupun peserta pemilu. Kepentingan peserta pemilu terhadap pemilih pemula berkaitan dengan suara, sedangkan bagi penyelenggara agar pemilih pemula berpartisipasi dalam pemilu.

Tulisan ini tidak ikut dalam arus pemikiran tersebut. Tetapi mencari sisi dalam memahami pendidikan pemilih. Sisi lain yang dimaksud dengan menempatkan pendidikan pemilih dalam tautannya dengan politik kewarganega- raan di satu sisi, sedangkan pada sisi yang lain, pendidikan pemilih bertautan dengan penguatan

\footnotetext{
${ }^{1}$ Paskarina Caroline, ,Instrumentasi Demokrasi:Pe ngelolaan Kekuasaan dalam Pe mbangunan', Jurnal Politik 7 No. 1 (2011): 57-76.

${ }^{2}$ Kenneth D. Wollack, Membuat Setiap Suara Punya Arti, (Jakarta, ELSAM, 1997).

${ }^{3}$ Joko J. Prihatmoko, Pemilu 2004 dan Konsolidasi Demokrasi (Semarang: LP2I dan LP3M Unwahas, 2003).

${ }^{4}$ Suryane f, dkk. ,Pe ndidikan Pe milih bagi Pe milih Pe mula serta Urgensinya dalam Pe mbangunan Demokrasi'. Prisiding SNAAP, Sosial, ekonomi dan Humaniora, 2015: 571-576.

${ }^{5}$ Husni Kamil Manik, dkk. Pedoman Pendidikan Pemilih (Jakarta: KPU, 2015).

${ }^{6}$ Setya Arinanto, ,Pe ndidikan Pe milih', Tempo, 2002.

7Santoso, ,Pe ndidikan Politik terhadap Pe milih Pe mula', Makalah, 2014.
} 
demokrasi. Dengan kata lain, tulisan ini ingin memberikan penafsiran lebih luas dalam meneropong gagasan pendidikan pemilih. Tulisan ini dimulai dengan konsepsi pendidikan pemilih. Konsepsi ini memberikan pijakan dalam memahami pendidikan pemilih. Selanjutnya melakukan pemaparan singkat mengenai literatur yang sejenis. Tujuannya adalah mendudukan bahwa tulisan ini berbeda dengan kajian sebelumnya. Penjelasan berikut menggambarkan tautan pendidikan pemilih dengan politik kewarganegaan, dan tautan pendidikan pemilih dengan demokrasi. Tulisan ini ditutup dengan beberapa catatan kritis.

\section{Makna Pendidikan pemilih}

Pendidikan pemilih sejatinya dilakukan secara terus menerus. Namun, fakta menunjukkan lain. Pendidikan pemilih hanya dilakukan menjelang pemilihan, dan aktor yang melakukan pendidikan pemilih adalah penyelenggara pemilu, partai politik, dan masyarakat sipil yang konsen dengan isu pemilu. Dengan aktor penyelenggara tersebut, maka kegiatan pendidikan pemilih selalu dimaknai dengan pemberian suara dan pemberian hak politik. Misalnya, Kenneth D Wollack, memaknai pendidikan pemilih adalah: membuatwarganegara memahami arti penting pemberian suara, mengerti hak pilih, mengetahui prosedur pemberian sua ra, dan memiliki pengetahuan untuk membuat piliha n-pilihan politik. ${ }^{8}$

Pendapat yang kurang lebih sama disampaikan Joko J Prihatmoko9, yang mengartikan pendidikan pemilih sebagai: kegiatan pendidikan politik yang dirancang secara sadar untuk memahami hal-ihwal pemilu dan partai politik, hubungan pemilu

${ }^{8}$ Wollack, Membuat Setiap, 49.

${ }_{9}$ Prihatmoko, Pemilu 2004 dan Konsolidasi, 192. 
dan demokrasi, proses pemilu, arti dan manfaat pemilu, prinsipprinsip pemilu yang jujur, adil dan demokratis.

Sedangkan Peraturan Komisi Pemilihan Umum [PKPU] No. 10/2018 tentang sosialisasi, pendidikan pemilih dan partisipasi masyarakat, mendefinisikan pendidikan pemilih sebagai proses penyampaian informasi kepada pemilih untuk meningkatkan pengetahuan, pemahaman, dan kesadaran pemilih tentang pemilu. Semua definisi tersebut memiliki titik temu, yakni memaknai pendidikan pemilih semata-mata berkaitan dengan pemberian hak suara dalam pelaksanaan pemilu. Warga masyarakat diberikan pengetahuan dan pemahaman persoalan pemilu, prosedur, dan tatacara memberikan suara. Ada kesan yang kuat bahwa dalam pendidikan pemilih berlangsung monolog dan membosankan. Warga masyarakat sebagai objek dari proses pendidikan pemilih. Nuansa formalistik sangat kental terasa. Padahal, hakikat dari pendidikan pemilih adalah membangun kesadaran kritis dan mengangkat martabat politik warganegara yang sebelumnya sebatas menjadi penonton, atau menjadi votes, yakni punya banyak pilihan dan voice yakni memiliki suara yang bermakna. ${ }^{10}$

Dengan kata lain, pendidikan pemilih membuat warganegara aktif, bukan saja dalam urusan pemberian suara, tetapi juga ikut berpartisipasi dalam proses politik yang lebih luas. Karena itu, pendidikan pemilih diharapkan pertama, menciptakan warganegara yang aktif. Kedua, membangunan warganegara yang kritis. ${ }^{11}$ Menghadirkan warganegara yang aktif dan kritis merupakan bagian penting dalam membangun demokrasi. Karena demokrasi menjamin partisipasi politik dan memungkinkan warganegara mengontrol kekuasaan politik.

${ }^{10}$ Ari Dwipayana, Menuju Pemilu Trandformatif (Jogjakarta: IRE, 2004), 38.

${ }_{11}$ Prihatmoko, Pemilu 2004 dan Konsolidasi, 193. 
Ketiga, meningkatkan partisipasi pemilih. Kesadaran tentang pentingnya penggunaan hak suara dalam pemilu dilakukan secara intensif dan meluas sehingga partisipasi pemilih dapat meningkat. Keempat, meningkatkan kualitas partisipasi pemilih. Angka kecurangan pemilih, konflik pemilih, dan mobilisasi pemilih dapat dikurangi sedemikian rupa melalui pendidikan pemilih yang berkualitas. Kelima, membantu penyelenggara pemilu. Semakin banyak pemilih yang paham dengan proses pemilu dan demokrasi dapat memudahkan dan meringankan kerja penyelenggara pemilu karena masing-masing sudah paham dengan proses dan bagaimana seharusnya pemilih bertindak ${ }^{12}$. Keenam, pendidikan pemilih akan membangun kesadaran kritis warganegara untuk memilih partai politik dengan bersandar pada ukuran akal sehat seperti kinerja partai politik selama duduk di lembaga politik. Ketujuh, pendidikan pemilih akan melahirkan gerakan anti-politik busuk dan anti politikus korup dalam pemilihan 2019. ${ }^{13}$

Daftar di atas menunjukkan bahwa pendidikan pemilih berkointribusi dalam menguatkan kapasitas warganegara yang berujung pada penguatan demokrasi. Pada titik inilah pendidikan pemilih perlu dilembagakan dan dilakukan secara berkelanjutan dan terencana karena merupakan bagian penting dari penguatan politik warganegara dan penguatan demokrasi substansial.

\section{Pemetaan kajian pendidikan pemilih}

Sebagian besar literatur yang mengkaji pendidikan pemilih selalu dikaitkan dengan pemilu. Kesan ini muncul setelah membaca dan menelaah sejumlah buku dan jurnal. Prihatmoko menyamakan

${ }^{12}$ Manik, dkk. Pedoman Pendidikan Pemilih, 2.

${ }^{13}$ Muhtar Haboddin, ,Menghadirkan Pe milih Pe mula Cerdas dalam Pe milu 2014', Jurnal Transformative 1, No. 1 (2015): 19. 
antara pendidikan pemilih dan pendidikan politik yang bermuara pada pembangu- nan demokrasi dan kesadaran politik. ${ }^{14}$ Selanjutnya, ia mengatakan bahwa pendidikan pemilih adalah kegiatan pendidikan politik. Cara berpikir ini perlu diberi catatan. Pertama, secara legal formal merujuk pada PKPU No 10/2018 tidak disebutkan kegiatan pendidikan pemilih adalah kegiatan pendidikan politik. Kedua, pendidikan pemilih merupakan ranah penyelenggara pemilu, sedangkan pendidikan politik merupakan salah satu fungsi partai politik.

Catatan lainnya, bahwa pendidikan pemilih bersifat temporer. Padahal dalam rangka mencerdaskan pemilih, seharus- nya pendidikan pemilih dilakukan secara terus menerus agar warganegara tersebut bisa berperan aktif dalam proses politik dan pemerintahan. Sedangkan Suryanef menulis pendidikan pemilih yang dikaitkan dengan pemilih pemula. ${ }^{15}$ Bagi Suryanef, melalui pendidikan pemilih diharapkan agar pemilih pemula berparti- sipasi dalam memberikan suaranya dalam pemilu. Namun, dampak partisipasi pemilih pemula dalam pembangunan demokrasi tidak dibicarakan lebih lanjutnya. Sejatinya, poin ini menjadi penting karena tindakan pemilihan akan bermakna apabila warga [citizen] kritis, dan aktif berpartisipasi dalam proses politik. Selanjutnya, karya Santoso yang berjudul pendidikan politik terhadap pemilih pemula ${ }^{16}$ Poin penting dari tulisan ini adalah pendidikan politik diharapkan memberikan kesadaran politik kepada pemilih pemula untuk terlibat dalam kegiatan politik. Meskipun demikian, tidak ditunjukkan bagaimana upaya yang bisa dilakukan dalam kerangka memberikan kesadaran politik. Sementara Haboddin memaparkan

\footnotetext{
${ }_{14}$ Prihatmoko, Pemilu 2004 dan Konsolidasi, 191-192.

${ }^{15}$ Suryane f, dkk. ,Pe ndidikan Pe milih, 571-576.

${ }_{16}$ Santoso, ,Pe ndidikan Politik, 2014.
} 
cara cerdas dalam melakukan pendidik pemilih. ${ }^{17}$ Yang berwenang dalam melakukan pendidikan pemilih adalah penyelenggara pemilu, partai politik, dan lembaga Lembaga Swadaya Masyarakat. Ketiga lembaga ini berkontribusi menyadarkan pemilih dalam menggunakan hak pilihnya. Dalam jajak pendapat Kompas, [2/4/2018] terungkap fakta tentang kesadaran pemilih yang akan menggunakan hak pilihnya dalam pemilih pemimpin mencapai 69,9 persen. Untuk lebih jelasnya lihat tabel 1.

Tabel 1. Pemilih maknai hak pilih

\begin{tabular}{cc}
\hline Memaknai hal pilih & Prosentase \\
\hline Wajib digunakan untuk memilih pemimpin & 69.9 \\
Hak pilih tidak wajib & 1,1 \\
Digunakan jika calon yang dipilih baik & 28,5 \\
Tidak tahu & 0,5 \\
\hline
\end{tabular}

Sumber: Kompas, 2/4/2018

Selain karya yang sudah disebutkan, lembaga KPU juga menerbitkan buku Pedoma $n$ Pendidikan Pemilih [2015]. Buku ini memberikan pedoman praktis dalam melakukan pendidikan pemilih. Hal ini nampak dari pembabakannya. Misalnya, tujuan, prinsip, sasaran, strategi, dan dilengkapi dengan materi pendidikan pemilih. Dengan kata lain, buku ini berisi petunjuk praktis pendidikan pemilih. Karena buku ini berisi petunjuk praktis, maka tidak mengaitkan pendidikan pemilih dengan penguatan politik warganegara dan demokrasi. Keterkaitan antara pendidikan pemilih dengan politik kewarganegaraan, pendidikan pemilih dengan demokrasi tergambar pada bagan 1 berikut ini.

${ }^{17}$ Haboddin, ,Menghadirkan Pe milih, 10-20 
Bagan 1. Keterkaitan pendidikan pemilih: politik warganegara dan demokrasi

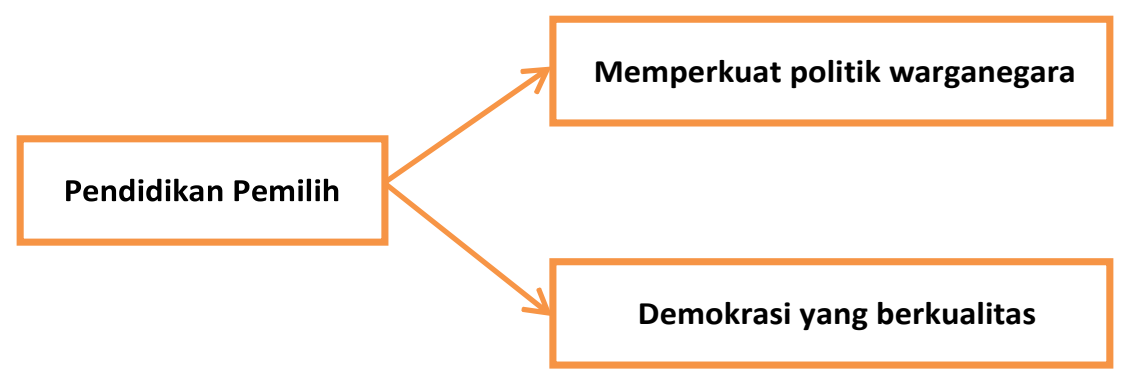

Bagan ini menunjukkan sisi lain dalam memahami pendidikan pemilih. Selain itu, bagan ini juga mengilustrasikan sebuah perbedaan dalam menelaah pendidikan pemilih. Perbedaan ini diperlukan supaya tidak terjadi pengulangan dan pada saat bersamaan menawarkan penjelasan berbeda perihal pendidikan pemilih. Selebihnya, diharap- kan tulisan ini melengkapi karya-karya sebelumnya.

\section{Pendidikan pemilih memperkuat politik kewarganegaraan}

Pendidikan terhadap pemilih perlu perluasan makna dan tidak sekedar terjalin dengan pemilu. Mengapa? Karena pendidikan pemilih akan memperkuat posisi warganegara [citizenship] dalam proses politik dan pemerintahan. Karena itu, pendidikan pemilih, tidak meluluh berbicara hak pilih, tetapi juga ikut bersuara [voice]. Pertama, bersuara hanya bisa dilakukan apabila warganegara tercerahkan, memiliki pengetahuan tentang hak dan kewajibannya. Bersuara berarti ikut menyuarakan aspirasi. Aspirasi bisa dibagi menjadi tiga. Pertama, keinginan individu atau masyarakat untuk keperluan jangka pendek yakni peruk dan kedudukan politik. Kedua, kebutuhan untuk memperbaiki persoalan bersama. Ketiga, 
kepentingan yang terkait dengan hak-hak sosial-ekonomi, dan politik. ${ }^{18}$

Kedua, pendidikan pemilih mendorong terjadinya berpartisipasi langsung warga negara dalam pemerintahan. Partisipasi masyarakat dalam pemerintahan sangat dimungkin- kan dalam sistem politik demokrasi. Dalam partisipasi politik, warganegara tidak hanya memilih pemimpin, tetapi juga turut membuat kebijakan publik, dan pengawasan proses politik. Studi Afan Gaffar yang berjudul merangsang partisipasi politik rakyat menyebutkan empat bentuk. Pertama, lobbying yaitu tindakan warganegara untuk menghubungi pejabat pemerintah atau pun tokoh politik tersebut yang menyangkut masalah yang mempengaruhi kehidupan mereka. Kedua, organiza tiona l activity, yaitu keterlibatan warganegara ke dalam organisasi sosial dan politik, apakah itu sebagai pimpinan, aktivis, atakah sebagai anggota biasa. Ketiga, contracting, yaitu partisipasi yang dilakukan oleh warga negara dengan secara langsung mendatangi pejabat pemerintah ataupun tokoh politik, baik dilakukan secara individual atau pun dalam kelompok. Keempat, violence yaitu partisipasi dengan menggunakan cara-cara kekera- san untuk mempengaruhi pemerintah. ${ }^{19}$

Empat bentuk partisipasi tersebut, hanya bisa dilakukan bila warga negara memiliki pengetahuan, pemahaman dan kesadaran kritis terhadap proses politik yang sedang berlangsung. Lobbying dan contracting sangat mudah dilakukan oleh warga negara dengan cara menghubungi langsung atau mendatangi langsung pejabat

${ }_{18}$ Sutoro Eko, Daerah Inklusif: Pembangunan, Demokrasi Lokal, dan Kesejahteraan. (Jogjakarta, IRE, TAF dan Ausaid, 2013), 30.

${ }^{19}$ Afan Gaffar, ,Merangsang Partisipasi Politik Rakyat' dalam Syarofin Arba [ed], Demitologisasi Politik Indonesia (Jakarta, CIDES, 1998), 241-242. 
pemerintahan bersangkutan. Selain itu, warga negara juga menggunakan sarana organisasi dalam membangun koneksitas dengan pejabat publik. Karena itu, bentuk partisipasi warga negara, baik Lobbying, organiza tiona $l$ activity, dan contracting merupakan instrumentasi yang berguna dalam membangun jejaring dan koneksitas dengan pejabat politik dalam lingkup pemerintahan.

Ketiga, pendidikan pemilih bisa mencerdaskan warga negara mengguna- kan media massa sebagai intrumentasi penyampaikan aspirasi, tuntutan, dan kritik kepada pemerintah. Warga negara yang memiliki pengetahun dan kesadaran politik akan menggunakan media massa dalam membangun komunikasi politik dengan pejabat publik. Begitu pula sebaliknya, pemerintah atau pejabat publik pun bisa menggunakan media massa dalam merespon tuntutan, keinginan, keluhan, dan kritik yang ditujukan kepadanya. McNair menyebut fenomena ini sebagai politik dalam era media. ${ }^{20}$ Maksudnya, media sebagai aktor mediasi antara warga negara dengan pemerintah. Untuk lebih jelasnya bisa disimak bagan 2.

\section{Bagan 2. Media sebagai instrumen mediasi}

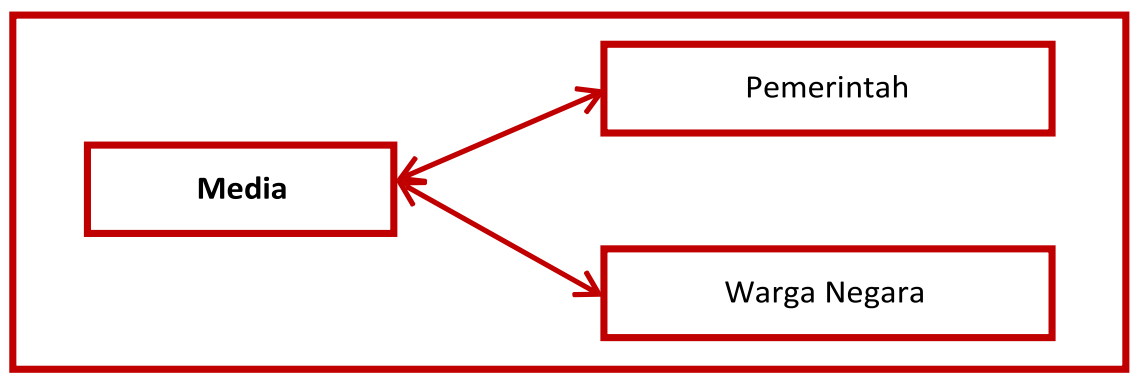

${ }^{20}$ Blian McNair, An Introduction to Political Cammunication, (London:

Routledge, 2004), 96. 
Bagan 2 menempatkan pesan sentral media sebagai mediasi antara pemerintah dengan warga negara. Karena itu, kenetralan media dalam pemberitaan menjadi penting. Dalam sistem politik yang demokratis media adalah penyam- bung lidah pemerintah dan masyarakat. Karenanya, warga negara yang cerdas akan menggunakan media sebagai alat untuk berkomunikasi dengan pemerinta- han. Bahkan, di era sekarang ini, media internet mengkoneksikan relasi pemerintah dengan masyarakat. Kompas, [19/3/2018] menyebut internet dianggap bisa memantapkan proses demokrasi agar lebih deliberatif dan inklusif.

Keempa t, pendidikan pemilih memperkuat posisi warga negara dihadapan pemerintah dan politisi. Salah gerakan warga negara dalam menjinakkan pemerintah melalui kontrak politik. Kontrak politik merupakan gerakan sadar politik yang mensyaratkan calon pemimpin politik untuk setia pada nilai-nilai yang ditawarkan dalam kontrak tersebut. Nilai-nilai yang terkandung dalam kontrak politik adalah [a]. Pejabat publik dituntut untuk memiliki komitmen yang kuat dalam membela dan memperjuangkan nasih warga negara; [2] tuntutan kepada pejabat publik untuk menghadirkan suatu proses politik dan pemerintahan yang transparan dan akuntabel; [3] tuntutan untuk pemerintahan menghadirkan pemerintahan yang bebas korupsi, kolusi dan nepotisme menuju terwujudnya pemerintahan yang baik; [4] tuntutan untuk menghilangkan adanya pemerintahan yang elitisme dan feodalisme politik; [5] tuntutan untuk menjadikan nilai-nilai lokal sebagai kultur politik; [6] tuntutan untuk mengentaskan kemiskinan. ${ }^{21}$

Poin-poin yang terkandung dalam kontrak politik merupakan bukti betapa tingginya kesadaran politik warga negara. Warga

${ }^{21}$ Widya Hari Murdianto, Demokrasi Lokal Ala Pikkada ( Jogjakarta: APMD Press, 2006), 209. 
negara mengikat pejabat publik sebelum berkuasa. Cara ini merupakan bentuk berpolitik yang bermartabat. Selain itu, kontrak politik ini akan menjadi pegangan diantara kedua belah pihak, yang pemerintah dan yang diperintah. Cara ini memiliki dasar yang kuat dalam filsafat politik. Thomas Hobbes merupakan rujukan yang pasti dalam tradisi kontrak politik. Dalam karya Laviatan, Hobbes menulis: saya mewenangkan dan menyerahkan hak saya atas pengaturan saya kepada pemimpin ini, dengan syarat ini Anda melepas hak Anda kepada pemimpin dan mewewenangkan.22 Dengan kata lain, pemimpin politik bertindak sebagaimana yang disepakati bersama.

Kelima, pendidikan kepada pemilih membuat warga negara semakin kritis dan rasional. Pendidikan pemilih memang diorientasikan agar warga negara kritis dan rasional dalam menyuarakan politiknya. Kritisme dan rasionalisme pemilih bisa ditujukan dengan berani menangih akuntabilitas politisi dan partai politik yang sedang duduk di lembaga nega ra. Warga nega ra harus rewel dan terus mempertanyakan apa yang sedang dan sudah dilakukan peja bat publik buat mereka. Metode menuntut progress report politisi ata u peja bat publik akan menghadirkan fungsi kontrol. ${ }^{23}$

\section{Pendidikan pemilih menciptakan demokrasi berkualitas}

Pendidikan pemilih juga bisa menciptakan demokrasi yang berkualitas. Hal ini diyakini Husni ${ }^{24}$ bahwa pendidikan pemilih membentuk nilai kesadaran, peran, hak, dan tanggungjawab warga negara dalam sistem demokrasi. Pemahaman ini diperkuat melalui Jajak Pendapat Kompas yang menyebutkan bahwa partisipasi pemilih

\footnotetext{
${ }^{22}$ Ahmad Suhe lmi, Pemikiran Politik Barat. (Jakarta: Grame dia, 2001), 176.

${ }^{23}$ Dwipayana, Menuju Pemilu Trandformatif, 42.

${ }^{24}$ Manik, dkk., Pedoman Pendidikan Pemilih, 2.
} 
menentukan kualitas demokrasi. Kualitas demokrasi bisa dikaitkan dengan tingkat partisipasi pemilih warga negara. Lihat tabel 2.

Tabel 2. Partisipasi pemilih menentukan kualitas Demokrasi

\begin{tabular}{cc}
\hline Jawaban & Persen \\
\hline Setuju & 88,1 \\
Tidak setuju & 7,7 \\
Tidak tahu & 4,2 \\
\hline
\end{tabular}

Sumbe r: kompas, 2 April 2018

Tabel 2 menunjukkan keterkaitan partisipasi dengan kualitas demokrasi. Sebanyak 88,1 persen warga negara meyakini partisipasi pemilih akan menentukan kualitas demokrasi. Logika- nya adalah semakin tinggi partisipasi warga negara, maka semakin besar legitimasi politik pemimpin terpilih. Legitimasi politik diperlukan dalam kerangka mengukuhkan kekuasaan. Disinilah arti pentingnya pendidikan pemilih dalam memperkuat demokrasi. Selanjutnya, dalam Jajak Pendapat Kompas pada bulan Juli 2018 melansir temuan baru perihal seberapa demokratiskah negara kita? Sebanyak 72 persen menjawab negara ini sudah demokratis dan 10 persen mengatakan sangat demokratis. Lihat tabel 3

Tabel 3. Seberapa demokratiskah negara kita?

\begin{tabular}{cc}
\hline Jawaban & Persen \\
\hline Demokratis & 72 \\
Sangat Demokratis & 10 \\
Tidak Demokratis & 8 \\
Sangat tidak Demokratis & 1 \\
Tidak tahu & 9 \\
\hline Sumber:
\end{tabular}

Sumber: Kompas, 20 Juli 2018

Meskipun Jajak Pendapat Kompas dilakukan dalam waktu yang berbeda [lihat tabel 2 dan 3] tetapi memiliki benang yang sama, 
yakni suara warga negara yang semakin matang dalam memberikan penilaian terhadap perkembangan demokrasi bangsa ini dalam beberapa tahun terakhir. Penilaian warga negara tersebut, seakanakan membantah pesisme sebagian pengamat yang mengatakan bahwa demokrasi Indonesia sudah stagnasi. ${ }^{25}$ Periksalah tabel 3 yang menyebutkan 10 persen bangsa ini sangat demokratis.

Selain pendidikan pemilih bisa membentuk kesadaran politik, juga dengan kasadaran itu mereka bisa mengontrol isu-isu publik. Karena itu, pemaknaan demokrasi berubah dan tidak lagi dipahami sebagai bentuk pemerintah, tetapi kemampuan warga negara melakukan kontrol terhadap isu-isu publik. Warga negara diposisikan sebagai aktor yang memiliki kapasitas untuk mengontrol isu-isu publik. Isu-isu publik yang mendapat perhatian dari warga negara tergambar pada grafik 1 berikut ini:

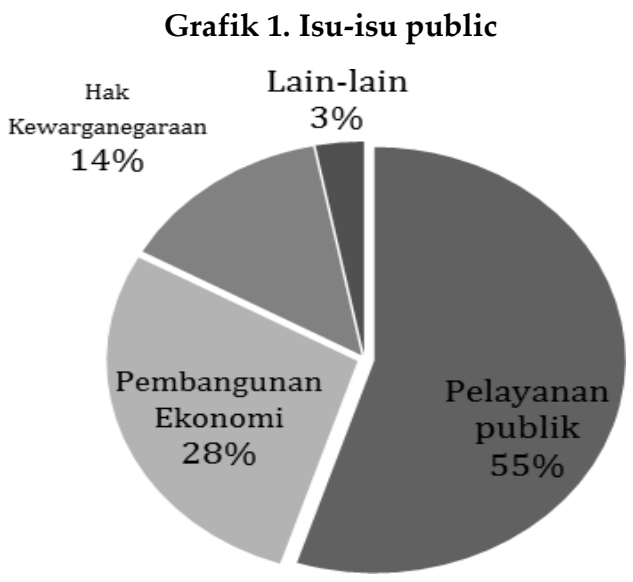

Sumber: Savirani ${ }^{26}$, dan Haboddin ${ }^{27}$

${ }^{25}$ Marcus Mietzne r, ,Indonesia Democratic Stagnation', Jurnal Democratization 19, No.2 (2012): 209-229.

${ }^{26}$ Amalinda Savirani, dkk., Demokrasi di Indonesia: Antara Patronase dan Populisme (Jogjakarta: UGM-Universitas Oslo, 2014), 10. 
Grafik di atas menunjukkan bahwa pelayanan publik menempati urutan pertama dengan nilai 55 persen. Pelayanan publik dalam kesehatan dan pendidikan menjadi perhatian bagi masyarakat. Warga negara ingin mendapatkan hak-hak dasar itu dari kebijakan pemerintah. Karena itu, dalam beberapa tahun terakhir, isu publik seperti kesehatan gratis dan pendidikan gratis menjadi kebijakan populis dalam politik Indonesia. Selain itu, isu publik yang menjadi perhatian berikutnya adalah pembangunan ekonomi. Pembangunan ekonomi menduduki peringkat dua dengan skor 28 persen. Sedangkan hak kewarganegaraan sekitar 14 persen.

Meskipun isu-isu publik menjadi trend dalam politik, namun pertanyaan adalah siapakah yang seharusnya mengelola isu-isu? Savirani dan Tornquist ${ }^{28}$ dalam Reclaiming the State menyebutkan sejumlah institusi yang seharusnya mengelola isu-isu publik. Lihat tabel 4 .

Tabel 4. Institusi yang mengelola isu-isu publik

\begin{tabular}{cc}
\hline Jenis lembaga & Pe rsentase \\
\hline Individu & 3,2 \\
Ke luarga dan klan & 0,5 \\
Pasar & 5,9 \\
Oraganisasi masyarakat sipil & 8,1 \\
Pe merintah & 65,9 \\
Lembaga public & 6,4 \\
Tidak menjawab & 10 \\
\hline Sumber: Savirani dan Tornquist ${ }^{29}$ &
\end{tabular}

${ }^{27}$ Muhtar Haboddin, ,Populisme , Politik Pe rtahanan, dan Pe mimpin Lokal', disampaikan dalam Seminar Nasional dalamrangka Dies Natalis FISIP, Universitas Jenderal Soe dirman, 16 November 2017), 6.

${ }^{28}$ Amalinda Savirani dan Olle Tornquist (ed), Reclaiming The State. (Jogjakarta: Polgov dan PCD, 2016), 28.

${ }^{29}$ Ibid. 
Meskipun terdapat sejumlah institusi yang mengelola isu-isu piblik sebagaimana tergambar pada tabel 4, namun yang paling dominan untuk melaksanakan semua itu adalah negara/pemerintah. Sebanyak 65,9 persen respoden mengatakan bahwa isu- isu publik ditangani negara/pemerintah. Karena ditangani oleh negara atau pemerintah, maka warganegara melakukan kontrol terhadapnya. Selain itu, kesehatan dan pendidikan termasuk hak-hak dasar warganegara yang perlu didapatkan. Dalam beberapa kasus pemerintah daerah berlomba-lomba membuat kebija- kan ini sebagai daya tarik untuk mendapatkan simpati dari masyarakat. Misalnya, Kartu Pendidikan Gratis dan Kartu Kesehatan Gratis merebak disejumlah daerah. Kepala daerah berusaha membuat kebijakan ini dalam kerangka merespon keinginan dan tuntutan masyarakat. Sejalan dengan itu, dalam kampaye politik Jokowi 2014 pun kembali melemparkan isu dalam bentuk kartu: Kartu Indonesia Pintar [KIP] dan Kartu Indonesia Sehat [KIS]. KIP dan KIS merupakan kebijakan untuk memastikan bahwa warganegara mendapatkan jaminan untuk mendapatkan layanan kesahatan danpendidikan.

Keterlibatan negara/pemerintah dalam isu-isu publik bisa dibaca sebagai bentuk pertanggungjawaban dalam menjalankan fungsi dasarnya. Hal ini bisa terjadi karena warganegara semakin sadar dan kritis dalam menuntut hak-hak dasarnya. Dalam sejarah negara-negara kesejahteraan seperti di Eropa menunjuk-kan bahwa gerakan akar rumputlah yang menuntut negara memenuhi hak-hak kesejahteraan. Lebih khusus, pengalaman di negara Skandinavia, keterlibatan wara negara dan pemerintah dalam isu-isu kesejahteraan telah menguatkan Savirani dan Tornquist posisi tawar mereka dalam mengelola barang-barang politik. ${ }^{30}$

${ }^{30}$ Savirani dan Tornquist (ed), Reclaiming The State, 34. 
Selain pemilih melakukan kontrol terhadap isu-isu publik, yang dikalah penting untuk dilakukan adalah mengontrol kekuasaan. Kekuasaan yang baik, selalu membutuhkan kontrol dari masyarakat. Kontrol dari masyarakat sangat diperlukan dalam menjinakkan kekuasaan. Logikanya adalah pertama, kekuasaan sangat mudah disalahgunakan oleh pemimpin politik. Karena itu, diperlukan kontrol dari masyarakat agar tidak disalahgunakan. Kontrol masyarakat terhadap kekuasaan bisa dilakukan dengan cara meminta pertanggung-jawaban politik pemerintah secara berkala. Bisa juga melalui kritik terbuka kepada pemerintah. Tujuannya adalah menormalkan kekuasaan yang memiliki motif represif, predator, dan sewenang- wenang.

Kedua , karena kekuasaan berasal dari masyarakat, maka sejatinya kekuasaan itu diabdikan kepada masyarakat. Bahkan, semua aktivitas dari operasionalisasi kekuasaan bermuara pada kepentingan masyarakat. Cara mengabdikan kekuasaan kepada pemiliknya dengan wataknya yang keras. Kekuasaan perlu dipahami sebagai instrumentasi untuk menciptakan kesejahteraan. Kekuasaan yang baik, tentu kekuasaan yang mensejaterakan warganegara. Maksudnya, adalah semua sumberdaya berada dalam ruang-lingkup kekuasaan dikelola untuk kesejahteraan warganegara.

Dengan demikian, maka pamahaman demokrasi mulai bergeser. Demokrasi kemudian dimaknai sebagai alat untuk mengubah dan pengelolaan urusan-urusan publik menjadi lebih terkontrol oleh warganegara atas dasar prinsip kesejahteraan. Dalam konteks ini, maka instrumentasi demokrasi menjadi proses untuk 
mengelola pola-pola relasi kekuasaan tersebut dalam rangka penciptaan kesejahteraan bagi warga- Negara. ${ }^{31}$

\section{Penutup}

Pendidikan pemilih memang sangat penting dalam demokrasi. Demokrasi yang dimaksud adalah demokrasi prosedural-minimalis yang sangat mengandalkan pelaksanaan dan proses pemilu. Sebagian literatur yang digunakan menyasar dan berujung pada pemilu. Dengan kata lain, pendidikan pemilih semata-mata diperuntukkan agar pemilih memiliki kesadaran, pemahaman perihal penggunaan hak pilih dalam pemilu. Padahal dalam memahami pendidikan pemilih bisa tarik lebih luas, yakni tidak sekedar urusan memilih, tetapi dikaitkan dengan politik kewarganegaraan dan penguatan demokrasi.

Tulisan ini mengambil jalan itu, dengan mengaitkan pendidikan pemilih dengan kewarganegaraan dan penguatan demokrasi. Pemilih yang cerdas dan kritis bisa menjadi warganegara yang akttif dalam menggunakan hak-hak politiknya melalui berpartisipasi dalam proses politik, mengawal isu-isu publik yang berkaitan dengan hak-hak dasar mereka, dan mengontrol kekuasaan. Lebih jauh lagi, pemilih dapat menempatkan demokrasi sebagai mekanisme pertuka- ran politik untuk mendapatkan akses terhadap sumberdaya, sehingga bekerjanya demokrasi diukur dari kapasitasnya untuk memenuhi permina- taan waranegara tersebut. Bagi warganegara, demokrasi memiliki nilai pragmatis untuk memenuhi kebutuhan sehari-hari secara cepat. ${ }^{32}$

Cara pandang ini memberikan nilai baru dalam memahami pendidikan pemilih dalam tautannya dengan demokrasi. Selain itu,

31 Caroline, ,Instrumentasi Demokrasi, 68.

32 Caroline, ,Instrumentasi Demokrasi, 70. 
gagasan demokrasi pun mengalami berubahan makna. Bahkan, demokrasi menempatkan warganegara sebagai aktor yang melakukan kontrol terhadap isu publik. Hal ini hanya bisa dilakukan apabila warganegara memiliki pengetahuan dan pemahaman terhadap peran, hak, dan kewajiban sebagai aktor politik. Selebihnya, warganegara harus aktif dalam menyuarakan keinginan, tuntutan, dan kepentingannya kepada pemerintah. Ini tantangan terbesar sebagai warganegara yang cerdas, kritis, dan bermartabat tinggi.

\section{Daftar Pustaka}

Amalinda Savirani dan Olle Tornquist (ed). 2016. Reclaiming The State. Jogjakarta: Polgov dan PCD.

Arinanto, Setya, 2002. 'Pendidikan Pemilih' Tempo.

Caroline, Paskarina. 2011. 'Instrumentasi Demokrasi:Pengelolaan

Kekuasaan dalam Pembangunan'. Jurnal Politik. Vol7.No.1. hlm.57-76

Dwipayana, Ari. 2004. Menuju Pemilu Trandformatif. Jogjakarta, IRE.

Eko, Sutoro. 2013. Daerah Inklusif: Pembangunan, Demokrasi Lokal, dan Keseja hteraan. Jogjakarta, IRE, TAF dan Ausaid.

Gaffar, Afan. 'Merangsang Partisipasi Politik Rakyat' dalam Syarofin Arba [ed].1998. Demitologisasi Politik Indonesia . Jakarta, CIDES. Haboddin, Muhtar. 2015. 'Menghadirkan Pemilih Pemula Cerdas dalam Pemilu 2014' Jurnal Transforma tive, Vol.1. No.1 Maret. hlm10-20.

Haboddin, Muhtar. 2017. ‘Populisme, Politik Pertahanan, dan Pemimpin Lokal', disampaikan dalam Seminar Nasional dalam rangka Dies Natalis FISIP, Universitas Jenderal Soedirman, 16 November 2017.

Husni Kamil Manik, dkk. 2015. Pedoman Pendidikan Pemilih. Jakarta, 
KPU.

McNair, Blian. 2004. An Introduction to Politica l Cammunication, London Routledge.

Mietzner, Marcus, 2012. 'Indonesia Democratic Stagnation' Jurnal Democratization, Vol.19.No.2, hlm. 209-229.

Murdianto, Widya Hari. 2006. Demokrasi Lokal Ala Pikkada. Jogjakarta, APMD Press.

Prihatmoko, Joko J. 2003. Pemilu 2004 dan Konsolidasi Demokrasi. Semarang, LP2I dan LP3M Unwahas.

Santoso [2014] 'Pendidikan Politik terhadap Pemilih Pemula'. Makalah.

Savirani, Amalinda, dkk. 2014. Demokrasi di Indonesia : Antara Patronase dan Populisme. Jogjakarta, UGM- Universitas Oslo Suhelmi, Ahmad. 2001. Pemikiran Politik Barat. Jakarta. PT.Gramedia.

Suryanef, dkk. 2015. 'Pendidikan Pemilih bagi Pemilih Pemula serta Urgensinya dalam Pembangunan Demokrasi' Prisiding SNAAP, Sosial, ekonomi dan Humaniora . hlm. 571-576.

Wollack, Kenneth D. 1997. Membuat Setiap Suara Punya Arti. Jakarta, ELSAM. 